\title{
A New Stability-Indicating HPLC Method for Simultaneous Determination of Curcumin and Celecoxib at Single Wavelength: an Application to Nanoparticulate Formulation
}

\section{Dalapathi B Gugulothu and Vandana B Patravale*}

Department of Pharmaceutical Sciences and Technology, Institute of Chemical Technology, N.P.Marg, Matunga, Mumbai 400019, India

\begin{abstract}
A simple, precise, isocratic, reverse phase high performance liquid chromatography (HPLC) method was developed for the simultaneous determination of curcuminoids: viz. curcumin(C), desmethoxycurcumin (DMC), bisdesmethoxycurcumin (BDMC) and celecoxib at single wavelength using a Agilent RP C18, $4.6 \mathrm{~mm} \times 150 \mathrm{~mm}$, $5 \mu \mathrm{m}$ XDB column. The run time was $18 \mathrm{~min}$. The influence of mobile phase composition, injection volume, mobile phase $\mathrm{pH}$, flow rate, temperature, and detector wavelength on resolution was investigated. The method was validated with respect to precision, accuracy, and linearity. The LOD and LOQ were found to be 0.3 and $1 \mu \mathrm{g} / \mathrm{mL}$, respectively for curcumin and 0.03 and $0.1 \mu \mathrm{g} / \mathrm{mL}$ for respectively for celecoxib. Linearity range was from $1-20 \mu \mathrm{g} /$ $\mathrm{mL}$ for curcumin and from $0.1-2 \mu \mathrm{g} / \mathrm{mL}$ for celecoxib. Further, the proposed method was found to be reproducible and convenient for stability-indicating analysis of curcumin-celecoxib pH sensitive nanoparticles.
\end{abstract}

Keywords: High performance liquid chromatography; Method validation; Stability indicating; Curcumin; Celecoxib; Nanoparticles

\section{Introduction}

It is a well known fact curcumin; a coloring principle in turmeric has emerged as the most exploited phyto-constituents for its wide spectrum of biological activities. Mostly, it is available in the market as a mixture of three different constituents, commonly known as curcuminoids. These curcuminoids constitute majorly $75 \%$ curcumin (curcumin I), followed by $20 \%$ desmethoxycurcumin (curcumin II) and to smaller extent bisdesmethoxycurcumin (curcumin III, 5\%) (Figure 1) [1]. Research over the last two decades has shown curcumin to be a potent antioxidant, anti-inflammatory, anti-proliferative, anti-metastatic, anti-angiogenic, anti-diabetic, hepatoprotective, antiatherosclerotic, anti-thrombotic, and anti-arthritic agent [2]. Structurally, curcumin is 1,7-bis (4-hydroxy-3-methoxyphenyl)-1,6-heptadiene-3,5-dione, desmethoxycurcumin is 1,6-Heptadiene-3,5-dione,1-(4-hydroxy-3methoxyphenyl)-7-(4-hydroxyphenyl) and bisdesmethoxycurcumin is 1,7-bis (4-hydroxyphenyl) hepta-1,6-diene-3,5-dione (Figure 1) [1,3]. These three molecules show very small chemical modifications with respect to their number of methoxy groups (none for bisdesmethoxycurcumin, one for desmethoxycurcumin and two for curcumin) and the presence of methoxy groups in the ortho position on the aromatic ring, [4]. However, these modifications influence the hydrophobic nature of three curcuminoids which is in the order of curcumin $>$ desmethoxycurcumin $>$ bisdesmethoxycurcumin, with curcumin being the relatively most hydrophobic among the three curcuminoids.

Celecoxib, 4-[5-(4-methylphenyl)-3-trifluoromethyl-1H-pyrazol1yl] benzene sulphonamide, is a 1,5-diaryl-substituted pyrazole with a pK of 11.1 (Figure 2). Celecoxib was the first specific inhibitor of cycloxygenase-2 (COX-2) with little or no effect on the gastrointestinal (GI) tract and kidney. It has been recommended for the treatment of rheumatoid arthritis, and osteoarthritis for its anti-inflammatory activity. Besides this, it also exerts analgesic and antipyretic, and does not inhibit platelet aggregation. It has also been used for treatment of colon cancer, ultraviolet (UV) light-induced skin cancer and breast cancer $[5,6]$.

Mechanistically, both curcumin and celecoxib utilize a different pathway to inhibit COX-2. It is believed that curcumin down-regulates COX-2 mRNA and protein levels, while celecoxib inhibits COX-2 activity directly by binding to its active site. Hence, the synergistic use of these drugs could augment the anti-inflammatory activity. This has
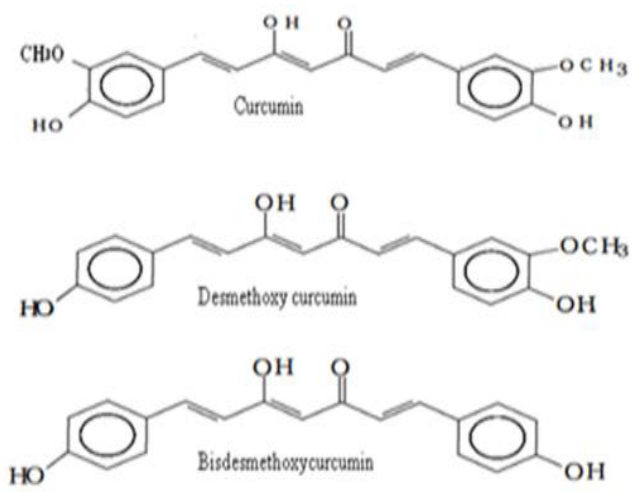

Figure 1: Chemical structure of curcuminoids: Curcumin, desmethoxycurcumin, and bisdesmethoxycurcumin.

${ }^{*}$ Corresponding author: Dr. Vandana B Patravale, Department of Pharmaceutical Sciences and Technology, Institute of Chemical Technology, N.P. Marg, Matunga, Mumbai 400019, India, Tel: +91-22-3361 2217; Fax: +91-22-3361 1020; E-mail: vbp_muict@yahoo.co.in

Received May 24, 2012; Accepted June 23, 2012; Published June 25, 2012

Citation: Gugulothu DB, Patravale VB (2012) A New Stability-Indicating HPLC Method for Simultaneous Determination of Curcumin and Celecoxib at Single Wavelength: an Application to Nanoparticulate Formulation. Pharmaceut Anal Acta 3:157. doi:10.4172/2153-2435.1000157

Copyright: ( 2012 Gugulothu DB, et al. This is an open-access article distributed under the terms of the Creative Commons Attribution License, which permits unrestricted use, distribution, and reproduction in any medium, provided the original author and source are credited. 


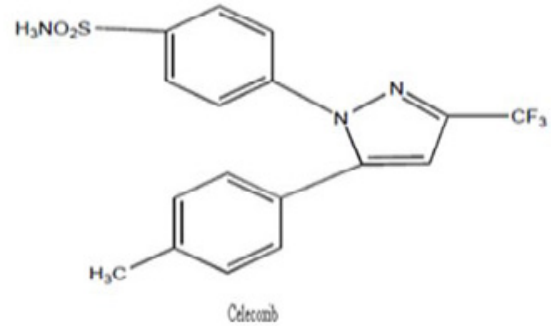

Figure 2: Chemical structure of celecoxib.

been demonstrated in osteoarthritis synovial adherent cells wherein curcumin synergistically enhances the growth inhibitory and proapoptotic effects of celecoxib [7].

Considering these benefits, it is worthwhile to explore the combination of both these drugs in treatment of inflammatory conditions. However, there is a dearth of suitable techniques for testing this combination in pharmaceutical dosage form. Although, there are many reported methods for the determination of curcumin [8-15] or celecoxib [16-22] in pharmaceutical dosage forms and biological fluids individually. The absence of suitable stability indicating method for the simultaneous determination of curcumin and celecoxib in presence of their degradants and their associated main impurities forms the underlying basis for this investigation.

To our knowledge, this is the first report of a stability indicating method for the simultaneous determination of both curcumin and celecoxib in nanoparticulate formulations. The present manuscript describes a simple, rapid, precise and accurate, reverse-phase stabilityindicating HPLC method for the simultaneous determination of curcumin and celecoxib in the nanoparticulate formulation.

\section{Experimental}

\section{Materials and reagents}

Curcumin (95\% purity) and Celecoxib (99\% purity) were obtained as gift samples from Konark Herbals Ltd, India and Cadila Pharmaceuticals Ltd., Ahmedabad, India respectively. HPLC grade acetonitrile, acetic acid, and triethanolamine were purchased from s.d. fine Chemicals (Mumbai, India). $0.45 \mu \mathrm{m}$ membranes were purchased from Pall Life Sciences. All other chemicals used were of analytical grade unless otherwise indicated.

\section{Chromatographic system and conditions}

The HPLC system consisted of Plus Intelligent LC pump PU-2080 from Jasco (Tokyo, Japan) equipped with a Jasco UV-2075 Intelligent UV/Vis detector and a Rheodyne 7725 injector (Rheodyne, Cotati, CA, USA). The output signal was monitored and processed using a Jasco Chroma Pass Chromatography Data System Software (Version 1.8.6.1). Chromatographic separation was achieved on a $5 \mu \mathrm{m}$ Agilent RP C ${ }_{18} \mathrm{XDB}$ column $(4.6 \mathrm{~mm} \times 150 \mathrm{~mm})$. The mobile phase employed comprised of Solvent A: Water (1\% acetic acid); adjusted to $\mathrm{pH}$ of 3.0 using $50 \%$ triethanolamine and Solvent B: Acetonitrile. Prior to use, water was filtered through a $0.45 \mu \mathrm{m}$ filter membrane. Mobile phase was pumped through the column at the flow rate of $1.50 \mathrm{~mL} /$ min. The injection volume was $20 \mu \mathrm{L}$. The analytes were analyzed at single wavelength; $254 \mathrm{~nm}$ for curcumin, celecoxib and their associated degradation products.

\section{Preparation of standard and sample solutions}

Stock solutions of curcumin $(200 \mu \mathrm{g} / \mathrm{mL})$ and celecoxib $(100 \mu \mathrm{g} /$ $\mathrm{mL}$ ) were separately prepared by dissolving accurately weighed $10 \mathrm{mg}$ of curcumin and $5 \mathrm{mg}$ of celecoxib in methanol using $50 \mathrm{~mL}$ volumetric flask. Standard solutions were prepared by dilution of the diluted stock solution with methanol to obtain solutions in the concentration range of $1-20 \mu \mathrm{g} / \mathrm{mL}$ and $0.1-2 \mu \mathrm{g} / \mathrm{mL}$ for curcumin and celecoxib respectively in $10 \mathrm{~mL}$ volumetric flask.

\section{Forced degradation of curcumin and celecoxib}

The standard solutions for the following studies were prepared by subjecting $1 \mathrm{~mL}$ of curcumin and $0.2 \mathrm{~mL}$ of celecoxib stock solutions (previously described) to various forced degradation conditions to provide an indication of the stability indicating property and specificity of the proposed method. Prior to analysis, the resultant mixture was diluted with methanol to give solutions containing curcumin and celecoxib in the concentrations of 20 and $2 \mu \mathrm{g} / \mathrm{mL}$ respectively.

\section{Preparation of acid- and base-induced degradation product}

To $1 \mathrm{~mL}$ of methanolic stock solution of curcumin and $0.2 \mathrm{~mL}$ of methanolic stock solution of celecoxib, $1 \mathrm{~mL}$ of $0.1 \mathrm{~N} \mathrm{HCl}$ and $1 \mathrm{~mL}$ of $0.1 \mathrm{~N} \mathrm{NaOH}$ were added separately. The acidic mixture was heated for $30 \mathrm{~min}$ at $80^{\circ} \mathrm{C}$, and basic mixture was heated for $10 \mathrm{~min}$ at $80^{\circ} \mathrm{C}$. Forced degradation in acidic and basic media was performed in $10 \mathrm{~mL}$ amber volumetric flasks in order to exclude the possible degradative effect due to light. The neutralized solutions were injected in triplicate and chromatograms were run as described.

\section{Preparation of hydrogen peroxide-induced degradation product}

To $1 \mathrm{~mL}$ of methanolic stock solution of curcumin and $0.2 \mathrm{~mL}$ of methanolic stock solution of celecoxib, $1 \mathrm{~mL}$ of hydrogen peroxide $(3 \%$ $\mathrm{v} / \mathrm{v}, \mathrm{H}_{2} \mathrm{O}_{2}$ ) was added. This solution mixture was heated for 1 hour at $80^{\circ} \mathrm{C}$. Forced degradation was performed in $10 \mathrm{~mL}$ amber volumetric flask in order to exclude the possibility of light induced degradation. The final solution was injected in triplicate and chromatogram was run as described previously.

\section{Photochemical degradation product}

$1 \mathrm{~mL}$ of methanolic stock solution and $0.2 \mathrm{~mL}$ of methanolic stock solution were diluted to $10 \mathrm{~mL}$ with methanol to give concentrations of 20 and $2 \mu \mathrm{g} / \mathrm{mL}$ of curcumin and celecoxib respectively, and photochemical stability of drugs was studied by exposing the stock solution to direct sunlight for 30 minutes.

\section{Heat-induced degradation product}

$1 \mathrm{~mL}$ of methanolic stock solution of curcumin and $0.2 \mathrm{~mL}$ of methanolic stock solution of celecoxib were taken in $10 \mathrm{~mL}$ amber volumetric flask and heated for 1 hour in water bath maintained at $80^{\circ} \mathrm{C}$ to study the heat degradation. The resultant cooled mixture was diluted to $10 \mathrm{~mL}$ with methanol, injected in triplicate and the chromatogram was run as described previously.

\section{Method Validation}

\section{Accuracy and precision}

Accuracy and precision determinations were carried out at $0.2,10$, $20 \mu \mathrm{g} / \mathrm{mL}$ and $0.2,1,2 \mu \mathrm{g} / \mathrm{mL}$ of curcumin and celecoxib concentrations respectively. At each level of the amount, six determinations were 
Citation: Gugulothu DB, Patravale VB (2012) A New Stability-Indicating HPLC Method for Simultaneous Determination of Curcumin and Celecoxib at Single Wavelength: an Application to Nanoparticulate Formulation. Pharmaceut Anal Acta 3:157. doi:10.4172/2153-2435.1000157

Page 3 of 6

performed, both intraday and interday variation were expressed in terms of \% RSD.

\section{Robustness of the method}

By introducing small changes in the mobile phase composition, injection volume, mobile phase $\mathrm{pH}$, flow rate, temperature and detector wavelength, the effects on the results were examined. In mobile phase; composition of solvent $\mathrm{B}$ was changed by $1 \%$, injection volume was changed from $20 \mu \mathrm{L}$ to $50 \mu \mathrm{L}$, $\mathrm{pH}$ of buffer was varied from 3.0 to 3.3 , flow rate was changed by 0.3 units, effect of column temperature was studied at $30^{\circ} \mathrm{C}$ and $40^{\circ} \mathrm{C}$, and detector wavelength was changed by 5 $\mathrm{nm}$. For most of the above conditions, the components of the mobile phase were held constant. Robustness of the method was studied in triplicate at a concentration level of 20 and $2 \mu \mathrm{g} / \mathrm{mL}$ for curcumin and celecoxib respectively [23].

\section{Limit of detection and limit of quantification}

LOD and LOQ, blank methanol was injected six times following the same method as explained previously. The LOD and LOQ for curcumin and celecoxib were estimated at $\mathrm{S} / \mathrm{N}$ of 3:1 and 10:1, respectively.

\section{Linearity}

Solutions for curcumin and celecoxib were prepared by diluting the stock solution to the required concentrations. Solutions were prepared from LOQ to $1,2,5,10,15,20 \mu \mathrm{g} / \mathrm{mL}$ and $0.1,0.2,0.5,1,1.5,2 \mu \mathrm{g} /$ $\mathrm{mL}$ for curcumin and celecoxib respectively. Calibration curves were drawn by plotting the peak areas of curcumin and celecoxib against the corresponding concentration. The slope and $Y$-intercept of the calibration curves were calculated.

\section{Solution stability}

The solution stability of curcumin and celecoxib was carried out by leaving a combined spiked sample $(20 \mu \mathrm{g} / \mathrm{mL}$ is of curcumin and $2 \mu \mathrm{g} / \mathrm{mL}$ of celecoxib) solution in a tightly capped volumetric flask at room temperature for 8 hours. Content of curcumin and celecoxib were determined by following the procedure as described previously.

\section{Analysis of curcumin and celecoxib from $\mathrm{pH}$ sensitive nanoparticles}

To determine the content of curcumin and celecoxib in freeze dried $\mathrm{pH}$ sensitive nanoparticles (label claim: $100 \mathrm{mg}$ of curcumin and $10 \mathrm{mg}$ of celecoxib), nanoparticles equivalent to $5 \mathrm{mg}$ of curcumin and $0.5 \mathrm{mg}$ of celecoxib were accurately weighed and transferred to a volumetric flask containing $50 \mathrm{~mL}$ methanol. To ensure complete extraction of drug, it was sonicated for $10 \mathrm{~min}$. The resulting solution was filtered through $0.45 \mu \mathrm{m}$ membrane and analyzed for drug content. Twenty microlitres (corresponding to 20 and $2 \mu \mathrm{g} / \mathrm{mL}$ for curcumin and celecoxib respectively) of filtered solution was injected and chromatogram was run as described previously. The analysis was repeated in six individual steps and the possibility of excipient interference in the analysis was also studied.

\section{Results and Discussion}

\section{Development of HPLC method}

Initially methanol and water were tried in various ratios for each drug individually and in combination. Celecoxib showed splitting peak nature whereas curcumin was unable to show three separate peaks. Then methanol was replaced by acetonitrile and used in various ratios, with the result that splitting peaks were observed for both drugs. Then both the drugs were tried with combination of methanol and water (1\% acetic acid; adjusted to $\mathrm{pH}$ of 3.0 using $50 \%$ triethanolamine) at various ratios, still curcumin was unable to separate into three peaks. Therefore, methanol was completely replaced with acetonitrile: water ( $1 \%$ acetic acid; adjusted to $\mathrm{pH}$ of 3.0 using $50 \%$ triethanolamine) in the ratio 45:55 (v/v) which exhibited good peak nature and peaks were found to be symmetrical at $254 \mathrm{~nm}$. Tailing factor for both the drug peaks was less than $2 \%$ with good resolution (Figure 3 ).

The linear regression data for the calibration curves $(n=3)$ (Table 1) showed a good linear relationship over a concentration range 1- 20 $\mu \mathrm{g} / \mathrm{mL}$ for curcumin and $0.1-2 \mu \mathrm{g} / \mathrm{mL}$ for celecoxib with respect to the peak area at $254 \mathrm{~nm}$. No significant difference was observed in the slopes of standard curves (ANOVA, $\mathrm{P}<0.0001$ ).

\section{Forced degradation of curcumin and celecoxib}

The chromatograms of samples subjected to various forced degradation conditions showed well separated chromatograms of pure curcumin (C), desmethoxycurcumin (DMC), bisdesmethoxycurcumin (BDMC), as well as some degradation peaks at different retention time, and celecoxib was found to be stable when subjected to various forced degradation conditions, as shown in (Figure 4-8). The number of degradation products, drug content of curcumin, and percentage recovery were calculated and are listed in Table 2.

\section{Acid- induced degradation product}

In addition to the curcuminoids peaks, the chromatogram of acid degraded sample of curcumin showed three additional peaks at 0.96 , 1.24 and $1.35 \mathrm{~min}$. Post $30 \mathrm{~min}$ heating on water bath, the areas of the

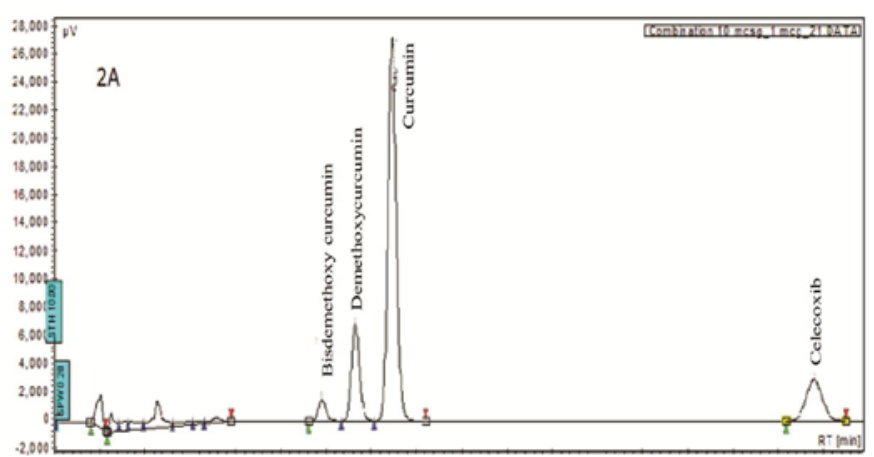

Figure 3: Chromatogram of curcumin $95 \%(20 \mu \mathrm{g} / \mathrm{mL})$ and celecoxib $(2 \mu \mathrm{g} /$ $\mathrm{mL}$ ) at $\lambda \max -254 \mathrm{~nm}$.

\begin{tabular}{|c|c|c|}
\hline Parameter & Curcumin & Celecoxib \\
\hline Linearity $(\mu \mathrm{g} / \mathrm{mL})$ & $1-20$ & $0.1-2$ \\
\hline Slope & $303.4 \pm 4.898$ & $702.6 \pm 10.85$ \\
\hline Y-intercept when $\mathrm{X}=0.0$ & $-43.52 \pm 54.94$ & $-1.790 \pm 12.17$ \\
\hline X-intercept when $\mathrm{Y}=0.0$ & 0.1434 & 0.002547 \\
\hline 1/slope & 0.003296 & 0.001423 \\
\hline 95\% Confidence Limit & \multicolumn{2}{|c|}{} \\
\hline Slope & 289.8 to 317.0 & 672.5 to 732.7 \\
\hline Y-intercept when $\mathrm{X}=0.0$ & 289.8 to 317.0 & 35.58 to 32.00 \\
\hline $\mathrm{X}$-intercept when $\mathrm{Y}=0.0$ & -0.3725 to 0.6244 & 0.04716 to 0.04901 \\
\hline $\mathrm{R}^{2}$ & 0.999 & 0.999 \\
\hline $\mathrm{P}$ value & $<0.0001$ & $<0.0001$ \\
\hline
\end{tabular}

Table 1: Linear regression data for calibration curve $(n=3)$. 
acid degraded product peaks were found to be higher than the area of standard curcumin concentration $(20 \mu \mathrm{g} / \mathrm{mL})$ indicating that curcumin undergoes significant degradation under mild acidic conditions $(0.1 \mathrm{~N}$ $\mathrm{HCl}$ ) and celecoxib was found to be stable (Figure 4). Drug recovery of acid-degradation product is given in Table 2 .

\section{Base-induced degradation product}

The chromatogram of base degraded sample showed additional peaks at $0.96,1.26$, and $1.36 \mathrm{~min}$. The presence of additional degradation peaks at mild conditions $(0.1 \mathrm{~N} \mathrm{NaOH}, 10$ min exposure) reconfirmed the vulnerability of curcumin to degradation in basic conditions and celecoxib was found to be stable (Figure 5). Drug recovery of base degradation product is given in Table 2 .

\section{Hydrogen peroxide-induced degradation product}

The chromatogram of curcumin treated with $\mathrm{H}_{2} \mathrm{O}_{2}(3 \% \mathrm{v} / \mathrm{v})$ showed additional peaks at 1.06 and $1.35 \mathrm{~min}$ and celecoxib was stable under this condition (Figure 6). Drug recovery of oxidation degradation product is given in Table 2 .

\section{Photochemical degradation product}

The chromatogram of curcumin exposed to photochemical

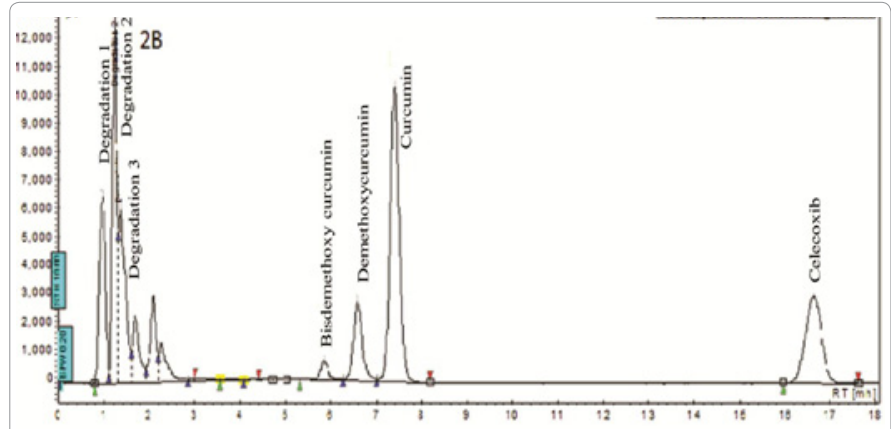

Figure 4: Chromatogram of acid $(0.1 \mathrm{~N} \mathrm{HCl})$ treated curcumin $(95 \%)$ and celecoxib.

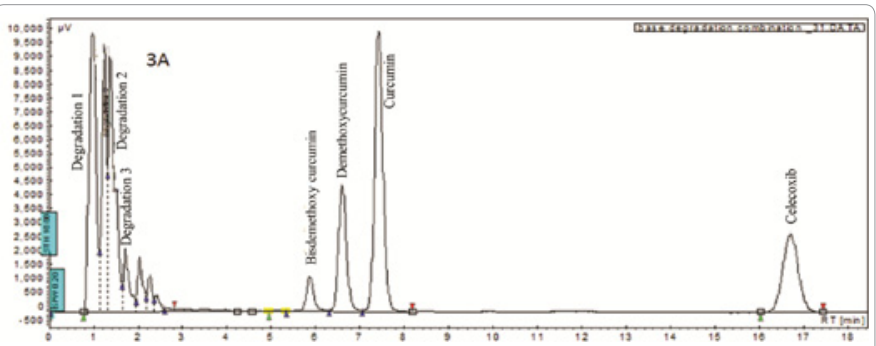

Figure 5: Chromatogram of base $(0.1 \mathrm{~N} \mathrm{NaOH})$ treated curcumin $(95 \%)$ and celecoxib.

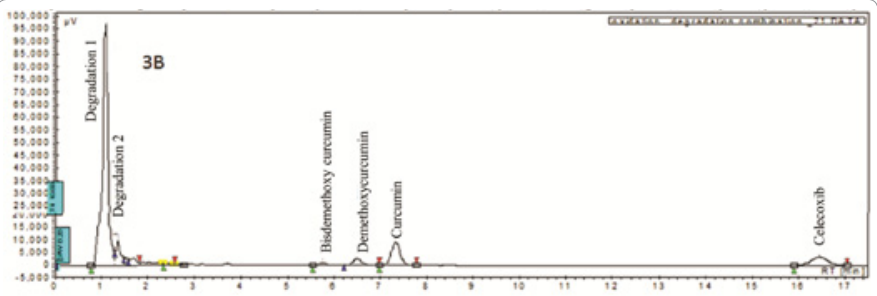

Figure 6: Chromatogram of oxidation $\left(3 \% \mathrm{v} / \mathrm{v} \mathrm{H}_{2} \mathrm{O}_{2}\right)$, treated curcumin (95\%) and celecoxib.

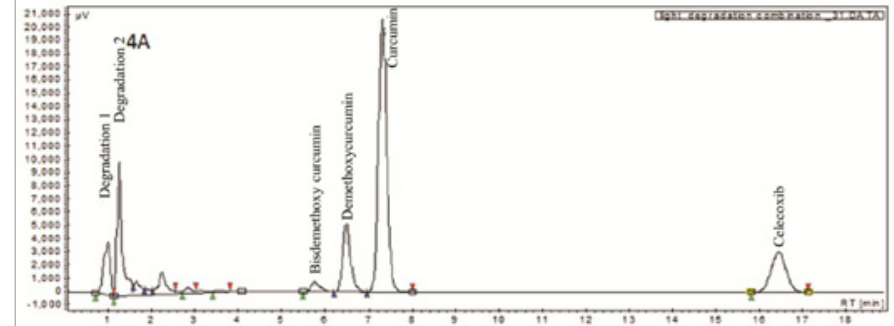

Figure 7: Chromatogram of photo degradation treated curcumin (95\%) and celecoxib.

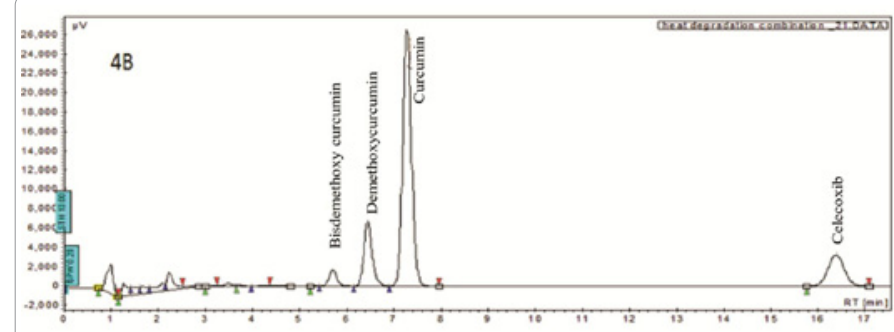

Figure 8: Chromatogram of heat degradation treated curcumin (95\%) and celecoxib.

degradation (sunlight for $30 \mathrm{~min}$ ) showed additional peaks at 1.008 and $1.25 \mathrm{~min}$. This indicates that the drug is unstable towards photochemical radiations for the exposure period under study and celecoxib was found to be stable towards light degradation (Figure 7). Drug recovery of photochemical degradation product is given in Table 2 .

\section{Heat degradation product}

The samples subjected to heat ( 1 hour water bath at $80^{\circ} \mathrm{C}$ ) conditions showed no additional peak for curcumin and celecoxib. This indicates that drugs were stable towards heat for the exposure period under study (Figure 8). Drug recovery of heat degradation product is given in Table 2.

\section{Method Validation}

\section{Accuracy and precision}

The accuracy and precision of the method were determined by spiking known amount of combined solution of curcumin and celecoxib in triplicate at low, medium and high levels of the specified limit. The measurement of the peak area showed low values of \% RSD $(<2)$ for inter and intraday variation, which suggested an excellent accuracy and precision of the method (Table 3-6).

\section{Robustness of the method}

\% RSD of peak areas was calculated for change in mobile phase composition, injection volume, mobile phase $\mathrm{pH}$, flow rate, composition of Solvent B was changed by $1 \%$, temperature, and detector wavelength at a combined concentration level of 20 and $2 \mu \mathrm{g} /$ $\mathrm{mL}$ for curcumin and celecoxib respectively in triplicate. The symmetry $(<2)$, asymmetry $(>2)$ and $\%$ RSD $(<2)$, obtained after introducing small deliberate changes in the developed HPLC method indicated the robustness of the method.

\section{Limit of detection and limit of quantification}

LOD and LOQ were calculated by the method as described previously, and were found to be 0.3 and $1 \mu \mathrm{g} / \mathrm{mL}$, and 0.03 and $0.1 \mu \mathrm{g} /$ 
Citation: Gugulothu DB, Patravale VB (2012) A New Stability-Indicating HPLC Method for Simultaneous Determination of Curcumin and Celecoxib at Single Wavelength: an Application to Nanoparticulate Formulation. Pharmaceut Anal Acta 3:157. doi:10.4172/2153-2435.1000157

Page 5 of 6

\begin{tabular}{|c|c|c|c|c|c|c|}
\hline & Curcumin & & & & & Celecoxib \\
\hline Sr. No & Exposure condition & $\begin{array}{l}\text { Time } \\
\text { (h) }\end{array}$ & $\begin{array}{l}\text { Drug remaining } \\
\qquad(\mu \mathrm{g} / \mathrm{mL})\end{array}$ & $\%$ of drug remaining & $\%$ RSD & Stability of celecoxib under subjected conditions \\
\hline 1 & Photo degradation & 0.5 & 15.33 & 76.65 & 0.82 & Stable \\
\hline 2 & Oxidation & 1.0 & 6.60 & 33.00 & 1.25 & Stable \\
\hline 3 & Base degradation & 0.6 & 7.60 & 38.01 & 0.69 & Stable \\
\hline 4 & Acid degradation & 1.0 & 8.058 & 40.29 & 0.089 & Stable \\
\hline 5 & Heat degradation & 1.0 & 20.04 & 100.203 & 1.69 & Stable \\
\hline
\end{tabular}

Table 2: Forced degradation studies of curcumin (95\%) and celecoxib.

\begin{tabular}{|c|c|c|c|c|c|c|}
\hline \multirow[b]{2}{*}{$\begin{array}{l}\text { Amount of added } \\
\text { drug }(\mu \mathrm{g} / \mathrm{mL})\end{array}$} & \multicolumn{3}{|l|}{ Inter-day accuracy } & \multicolumn{3}{|l|}{ Intra-day accuracy } \\
\hline & $\begin{array}{l}\text { Amount of drug } \\
\text { remaining }(\mu \mathrm{g} / \mathrm{mL})\end{array}$ & $\%$ of drug recovered & $\%$ RSD & $\begin{array}{l}\text { Amount of drug } \\
\text { remaining } \\
(\mu \mathrm{g} / \mathrm{mL})\end{array}$ & $\%$ of drug recovered & $\%$ RSD \\
\hline 2 & 1.98 & 98.33 & 1.00 & 2.049 & 102.45 & 0.480 \\
\hline 10 & 9.99 & 100.92 & 0.842 & 9.60 & 96.00 & 0.456 \\
\hline 20 & 20.1 & 100.15 & 20.25 & 20.25 & 101.25 & 0.263 \\
\hline
\end{tabular}

Table 3: Intra and inter-day accuracy and recovery studies of HPLC method $(n=6)$ : Curcumin.

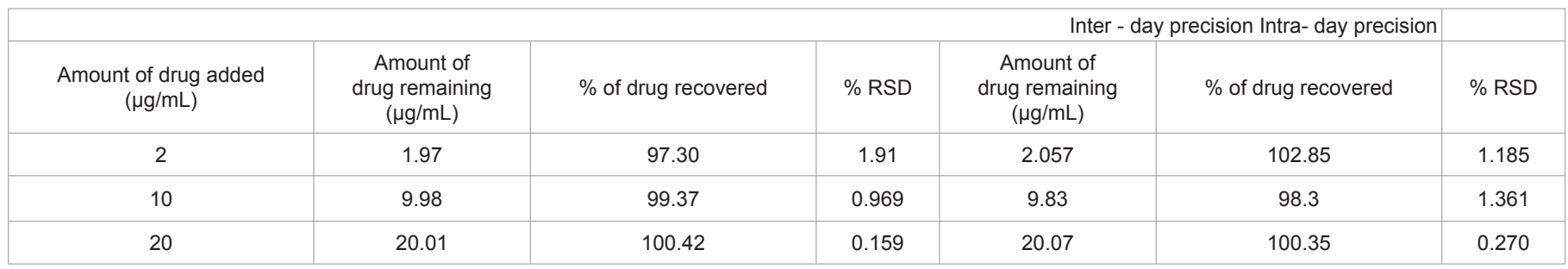

Table 4: Intra and inter-day precision and recovery studies of HPLC method $(n=6)$ : Curcumin.

\begin{tabular}{|c|c|c|c|c|c|c|}
\hline \multicolumn{4}{|c|}{ Inter-day accuracy } & \multicolumn{3}{|c|}{ Intra-day accuracy } \\
\hline $\begin{array}{l}\text { Amount of drug added } \\
\qquad(\mu \mathrm{g} / \mathrm{mL})\end{array}$ & $\begin{array}{l}\text { Amount of drug remaining } \\
\qquad(\mu \mathrm{g} / \mathrm{mL})\end{array}$ & $\begin{array}{l}\% \text { of drug } \\
\text { recovered }\end{array}$ & $\%$ RSD & $\begin{array}{l}\text { Amount of drug remaining } \\
\qquad(\mu \mathrm{g} / \mathrm{mL})\end{array}$ & $\begin{array}{l}\% \text { of drug } \\
\text { recovered }\end{array}$ & $\%$ RSD \\
\hline 0.2 & 0.192 & 96.37 & 0.154 & 0.2 & 100.09 & 1.4 \\
\hline 01 & 1.02 & 102.02 & 1.07 & 0.99 & 99.69 & 1.6 \\
\hline 02 & 1.97 & 98.92 & 0.986 & 2.01 & 100.99 & 0.59 \\
\hline
\end{tabular}

Table 5: Intra and inter-day accuracy and recovery studies of HPLC method $(n=6)$ : Celecoxib.

\begin{tabular}{|c|c|c|c|c|c|c|}
\hline \multicolumn{7}{|c|}{ Intra-day precision Inter-day precision } \\
\hline $\begin{array}{l}\text { Amount of drug } \\
\text { added }(\mu \mathrm{g} / \mathrm{mL})\end{array}$ & $\begin{array}{c}\text { Amount of } \\
\text { drug remaining } \\
(\mu \mathrm{g} / \mathrm{mL})\end{array}$ & $\begin{array}{l}\% \text { of drug } \\
\text { recovered }\end{array}$ & $\%$ RSD & $\begin{array}{c}\text { Amount of } \\
\text { drug } \\
\text { remaining } \\
(\mu \mathrm{g} / \mathrm{mL})\end{array}$ & $\begin{array}{l}\% \text { of drug } \\
\text { recovered }\end{array}$ & $\%$ RSD \\
\hline 0.2 & 0.192 & 96.22 & 0.25 & 0.198 & 99.00 & 0.67 \\
\hline 01 & 1.004 & 100.42 & 0.63 & 1.06 & 106.00 & 0.254 \\
\hline 02 & 1.970 & 98.97 & 0.241 & 1.98 & 99.00 & 0.18 \\
\hline
\end{tabular}

Table 6: Intra-and inter-day precision and recovery studies of HPLC method $(n=6)$ : Celecoxib.

$\mathrm{mL}$ for curcumin and celecoxib respectively, which indicates adequate sensitivity of the method.

\section{Solution stability}

$\%$ RSD for combined solution of curcumin and celecoxib concentrations during solution stability experiments was within $1 \%$. No significant changes were observed for the chromatograms of standard solution and the experimental solution. Further, absence of degradation peaks confirmed that the sample is stable in solvent used during the assay for 8 hours.

\section{Analysis of curcumin and celecoxib from $\mathrm{pH}$ sensitive nanoparticles}

In the chromatogram of curcumin-celecoxib samples extracted 
Citation: Gugulothu DB, Patravale VB (2012) A New Stability-Indicating HPLC Method for Simultaneous Determination of Curcumin and Celecoxib at Single Wavelength: an Application to Nanoparticulate Formulation. Pharmaceut Anal Acta 3:157. doi:10.4172/2153-2435.1000157

Page 6 of 6

from $\mathrm{pH}$ sensitive nanoparticles, separate peaks were observed corresponding to the three curcuminoids and celecoxib. There was no interference from the excipients commonly present in nanoparticles. The drug content was found to be 99.18 and $99.01 \%$ with a \% RSD of 0.017 and 0.028 respectively for curcumin and celecoxib. It may therefore be inferred that degradation of curcumin and celecoxib did not occur in the formulations that were analyzed by this method. The low \% RSD value indicated the suitability of this method for routine analysis of curcumin- celecoxib in pharmaceutical dosage forms.

\section{Conclusions}

The developed HPLC technique is precise, specific, accurate and stability- indicating for the determination of curcumin (95\%) and celecoxib. Statistical analysis also proves that the method is reproducible and specific for the analysis of curcumin along with its co-purified derivatives (desmethoxycurcumin and bisdesmethoxycurcumin) and celecoxib. This method is versatile in separate analysis of curcumin and celecoxib in $\mathrm{pH}$ sensitive nanoparticles.

\section{Acknowledgments}

The authors are grateful to University Grants Commission (UGC) for financial assistance, Konark Herbals Ltd., and Cadila Pharmaceuticals Ltd. for gift of samples of curcumin and celecoxib respectively.

\section{References}

1. Bansal SS, Goel M, Aqil F, Vadhanam MV, Gupta RC (2011) Advanced drug delivery systems of curcumin for cancer chemoprevention. Cancer Prev Res (phila) 4: 1158-1171.

2. Anand $P$, Thomas SG, Kunnumakkara AB, Sundaram $C$, Harikumar KB, et al. (2008) Biological activities of curcumin and its analogues (Congeners) made by man and mother nature. Biochem Pharmacol 76: 1590-1611.

3. Jayaprakasha GK, Jagan Mohan Rao L, Sakariah KK (2002) Improved HPLC method for the determination of curcumin, demethoxycurcumin and bisdesmethoxycurcumin. J Agri Food Chem 50: 3668-3672.

4. Jeong GS, Oh GS, Pae HO, Jeong SO, Kim YC, et al. (2006) Comparative effects of curcuminoids on endothelial heme oxygenase-1, expression: orthomethoxy groups are essential to enhance heme oxygenase activity and protection. Expt Mol Med 38: 393-400

5. Reddy MN, Rehana T, Ramakrishna S, Chowdhary KP, Diwan PV (2004) Betacyclodextrin complexes of celecoxib: molecular-modeling, characterization, and dissolution studies. AAPS PharmSci 6: E7

6. Baboota S, Faiyaz S, Ahuja A, Ali J, Shafiq S, et al. (2007) Development and validation of a stability indicating HPLC method for analysis of celecoxib (CXB) in bulk drug and microemulsion formulations. Acta Chromatogr 18: 116-129.

7. Ari SL, Strier L, Kazanov D, Elkayam O, Lichtenberg D, et al. (2006) Curcumin synergistically potentiates the growth-inhibitory and pro-apoptotic effects of celecoxib in osteoarthritis synovial adherent cells. Rheumatology (Oxford) 45: 171-177.

8. Ansari MJ, Ahmad S, Kohli K, Ali J, Khar RK (2005) Stability-indicating HPTLC determination of curcumin in bulk drug and pharmaceutical formulations. J Pharm Biomed Anal 39: 132-138.

9. Chauhan SK, Singh BP, Agrawala S (1999) Estimation of curcuminoids in curcuma longa by HPLC and spectrophotometric methods. Indian J Pharm Sci 61: 58-60.

10. Heath DD, Pruitt MA, Brenner DE, Rock CL (2003) Curcumin in plasma and urine: quantitation by high performamnce liquid chromatography. J Chromatogr B Anal Technol Biomed Life Sci 783: 287-295.

11. Pak Y, Patek R, Mayersohn M (2003) Sensitive and rapid isocratic liquid chromatography method for quantitation of curcumin in plasma. J Chromatogr B Anal Technol Biomed Life Sci 796: 339-346.

12. Cheng J, Weijun K, Yun L, Jiabo W, Haitao W, et al. (2010) Development and validation of UPLC method for quality control of Curcuma longa Linn.: Fast simultaneous quantitation of three curcuminoids. J Pharm Biomed Anal 53 43- 49.

13. Lechtenberg M, Quandt B, Nahrstedt A (2004) Quantitative determination of curcuminoids in Curcuma rhizomes and rapid differentiation of Curcuma domestica Val. and Curcuma xanthorrhiza Roxb. by capillary electrophoresis. Phytochem Anal 15: 152-158.

14. Nhujak T, Saisuwan W, Srisa-art M, Petsom A (2006) Microemulsion electrokinetic chromatography for separation and analysis of curcuminoids in turmeric samples. J Sep Sci 29: 666-676.

15. Inoue K, Amasaki SY, Yoshimura Y, Amada M, Nakamura M, et al. (2003) Validation of LC/Electrospray $\square$ MS for determination of major curcuminoids in foods. J Liq Chromatogr Relat Technol 26: 53-62.

16. Jadhav AS, Shingare MS (2005) A new stability--indicating RP-HPLC method to determine assay and known impurity of celecoxib API. Drug Dev Ind Pharm 3: 779-783.

17. Dhabu PM, Akamanchi KG (2002) A stability-indicating HPLC method to determine celecoxib in capsule formulations. Drug Dev Ind Pharm 28: 815-821.

18. Shakeel F, Baboota S, Ahuja A, Ali J, Shafiq S (2008) Accelerated stability testing of celecoxib nanoemulsion containing cremophor-EL. African Journal of Pharmacy and Pharmacology 2: 179-183.

19. Zhang M, Moore GA, Gardiner SJ, Begg EJ (2006) Determination of celecoxib in human plasma and breast milk by high-performance liquid chromatographic assay. J Chromatogr B Analyt Technol Biomed Life Sci 830: 245-248.

20. Saha RN, Sajeev C, Jadhav PR, Patil SP, Srinivasan N (2002) Determination of celecoxib in pharmaceutical formulations using UV spectrophotometry and liquid chromatography. J Pharm Biomed Anal 28: 741-751.

21. Schönberger F, Heinkele G, Mürdter TE, Brenner S, Klotz U, et al. (2002) Simple and sensitive method for the determination of celecoxib in human serum by high-performance liquid chromatography with fluorescence detection. J Chromatogr B Analyt Technol Biomed Life Sci 768: 255-260.

22. Hashem H, Trundelberg C, Jira T (2010) Chromatographic application o calixarene bonded stationary phases: A stability indicating LC-method for determination of celecoxib in tablet formulation. Chromatographia 71: 91-94.

23. Hayden YV, Jimidar M, Hund E, Niemeijer N, Peeters R, et al. (1999) Determination of system suitability limits with a robustness test. J Chromatogr A 845 : $145-154$ 